\title{
DETERMINAN PENYERAPAN KREDIT MODAL KERJA UNTUK USAHA KECIL
}

\author{
I Nengah Suarmanayasa ${ }^{1^{*}}$ \\ ${ }^{1}$ Universitas Pendidikan Ganesha, Indonesia \\ “e-mail: nengah.suarmanayasa@undiksha.ac.id
}

\begin{abstract}
Abstrak
Penelitian ini bertujuan untuk menguji pengaruh jumlah usaha kecil, PDRB, suku bunga kredit dan indeks harga konsumen baik secara simultan maupun parsial terhadap jumlah kredit modal kerja untuk usaha kecil di Bali. Penelitian ini menggunakan data triwulanan yang diperoleh dari Otoritas Jasa Keuangan, Badan Pusat Statistik, dan Bappeda Provinsi Bali dalam rentang waktu 8 tahun. Pengumpulan data dengan metode dokumentasi. Selanjutnya analisis data dengan regresi linear berganda model double log. Hasil penelitian menemukan: 1) jumlah usaha kecil, PDRB, suku bunga kredit dan indeks harga konsumen secara simultan berpengaruh signifikan terhadap jumlah kredit modal kerja, 2) Jumlah usaha kecil tidak berpengaruh terhadap jumlah kredit modal kerja, 3) Suku bunga kredit berpengaruh negatif dan signifikan terhdap jumlah kredit modal kerja, 4) PDRB berpengaruh positif dan signifikan terhadap jumlah kredit modal kerja, dan 5) Indeks harga konsumen berpengaruh positif dan signifikan terhadap jumlah kredit modal kerja untuk usaha kecil di Bali. Implikasi hasil penelitian ini adalah indikator makro ekonomi yang tercermin dari PDRB maupun tingkat inflasi menentukan kinerja perbankan terutama dalam hal penyaluran kredit. Untuk itu, pihak perbankan agar cermat dalam menentukan tingkat suku bunga kredit. Tinggi rendahnya suku bunga kredit perbankan merupakan faktor penting yang dipertimbangkan pelaku usaha kecil di Bali dalam mengembangkan usahanya.
\end{abstract}

Kata kunci: Kredit Modal Kerja; Usaha Kecil; Suku Bunga

\begin{abstract}
This study examines the effect of the number of small businesses, Gross Regional Domestic Product, credit interest rates, and consumer price index simultaneously and partially on the amount of working capital credit for small businesses in Bali. Over eight years, this study uses quarterly data obtained from the Financial Services Authority, the Central Bureau of Statistics, and the Bali Provincial Regional Development Agency. Data collection using the documentation method. Furthermore, data analysis using multiple linear regression double log model. The results of the study found: (1) the number of small businesses, Gross Regional Domestic Product, credit interest rates, and consumer price index simultaneously had a significant effect on the amount of working capital credit, (2) The number of small businesses had no effect on the amount of working capital credit, (3) Credit interest rates has a negative and significant effect on the amount of working capital credit, (4) Gross Regional Domestic Product has a positive and significant effect on the amount of working capital credit, and (5) The consumer price index has a positive and significant effect on the amount of working capital credit for small businesses in Bali. The implication based on the result of this study is that macroeconomic indicators reflected in GRDP nor inflation rates determine banking performance, especially in terms of lending. For this reason, banks must be punctilious in determining loan interest rates. The high and low interest rates on bank credit are essential factors that small business actors consider to develop their business in Bali.
\end{abstract}

Key words: Working Capital Credit, Small Business; Interest rate

This is an open access article under the CC BY-SA license.

Copyright @ 2021 by Author. Published by Universitas Pendidikan Ganesha.

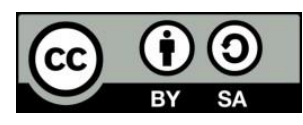




\section{PENDAHULUAN}

Pembangunan nasional bertujuan untuk mewujudkan masyarakat yang adil dan makmur yang merata material dan spiritual berdasarkan Pancasila dan Undang-undang Dasar 1945 (Indriani, 2016). Pembangunan nasional mencakup seluruh aspek kehidupan berbangsa yang diselenggarakan oleh masyarakat dan pemerintah. Perwujudan tujuan masyarakat yang adil dan makmur dapat berupa peningkatan jumlah lapangan kerja, pemerataan dan peningkatan pendapatan masyarakat, mendorong pertumbuhan ekonomi dan mewujudkan stabilitas nasional. Upaya tersebut sempat terhambat dengan adanya krisis ekonomi, krisis moneter serta serangan teroris dengan adanya bom Bali. Saat adanya gangguan tersebut, perekonomian Indonesia mengalami keterpurukan. Hal ini ditunjukkan dengan menurunnya nilai tukar rupiah terhadap dolar, banyak bank yang dilikuidasi, banyak usahausaha besar yang gulung tikar.

Kondisi berbeda terjadi pada usaha kecil. Usaha kecil tetap tegar saat adanya krisis ekonomi bahkan mampu memberikan kontribusi yang besar bagi perekonomian. Usaha kecil adalah usaha ekonomi produktif yang berdiri sendiri, yang dilakukan oleh orang perseorangan atau badan usaha yang bukan merupakan anak perusahaan atau bukan cabang perusahaan yang dimiliki, dikuasai, atau menjadi bagian baik langsung maupun tidak langsung dari usaha menengah dan usaha besar (Undang-Undang tentang Usaha Mikro, Kecil dan Menengah, 2008). Saat terjadi krisis ekonomi, usaha kecil terbukti mampu menampung 99,45 persen dari total tenaga kerja. Peranan usaha kecil, sejak krisis ekonomi dapat dipandang sebagai katup penyelamat dalam proses pemulihan ekonomi nasional, baik dalam mendorong laju pertumbuhan ekonomi maupun dalam hal penyerapan tenaga kerja. Usaha kecil merupakan benteng pertahanan ekonomi nasional sehingga bila sektor tersebut diabaikan sama artinya tidak menjaga benteng pertahanan Indonesia (Putra \& Rustariyuni, 2014).

Sebagai upaya untuk meningkatkan kemampuan dan peran serta usaha kecil dalam perekonomian nasional, maka diperlukan sinergitas secara menyeluruh dan berkesinambungan antara pemerintah dengan pelaku usaha. Untuk mewujudkan hal tersebut, pemerintah telah mengeluarkan undang-undang tentang usaha mikro, kecil dan menengah. UU ini disusun salah satu tujuannya untuk memberdayakan usaha kecil. Meskipun usaha kecil telah menunjukkan peranannya dalam perekonomian nasional, namun pelaku usaha kecil masih menghadapi hambatan dan kendala. Salah satu kendala yang masih menjadi penghambat kemajuan usaha adalah dalam hal permodalan. Bagi usaha kecil, kredit adalah hal mendesak untuk kebutuhan modal kerja serta untuk meningkatkan kemampuan berproduksi (Suarmanayasa, 2020).

Dalam pemenuhan kebutuhan modal, peran lembaga keuangan sangat penting. Sumber utama pembiayaan pada negara berkembang umumnya masih didominasi oleh kredit perbankan (Risal, 2019). Di Indonesia, industri perbankan menguasai sekitar 93 persen dari total asset industri keuangan. Sejalan dengan kebutuhan permodalan bagi usaha kecil, Bank Inonesia sebagai otoritas moneter dahulu pernah mengeluarkan paket kebijakan tahun 1990 . Kebijakan tersebut mewajibkan setiap bank mengalokasikan sebanyak 20 persen dari total kreditnya dalam bentuk kredit usaha kecil. Namun, pada tahun 2001, Bank Indonesia mengeluarkan peraturan nomor 3/2/PBI/2001 yang menyatakan bahwa pemberian kredit usaha kecil oleh pihak bank diserahkan kepada kemampuan masingmasing bank. Kebijakan ini menggugurkan kewajiban bank dalam pemberian alokasi kredit kepada usaha kecil. Di lain pihak, pemerintah serius dalam mendukung perkembangan dan kemajuan usaha kecil dengan mewajibkan pihak perbankan menyalurkan kredit pada pelaku usaha kecil. Kenyataan dalam prakteknya terdapat kendala dari sisi pelaku usaha kecil berupa ketidakmampuan dalam memenuhi persyaratan administrasi sehingga kesulitan untuk memperoleh kredit dari perbankan. Melihat besarnya peran usaha kecil dalam perekonomian dan masalah permodalan yang dihadapi, mengindikasikan belum maksimalnya peran pemerintah terhadap pengembangan usaha kecil (Putra \& Rustariyuni, 2014).

Ada banyak faktor yang memengaruhi penyerapan modal kerja untuk usaha kecil. Kredit modal kerja merupakan jumlah kredit modal kerja yang disalurkan 
oleh pihak bank yang peruntukkannya untuk pelaku usaha kecil. Tulisan ini membahas faktor yang memengaruhi penyerapan kredit modal kerja untuk usaha kecil di Bali yaitu jumlah usaha kecil, Produk Domestik Regional Bruto (PDRB), suku bunga kredit modal kerja dan indeks harga konsumen. Keputusan penyaluran kredit usaha kecil tidak terlepas dari jumlah usaha kecil itu sendiri. Usaha kecil identik dengan industri kecil dan industri rumah tangga. Usaha kecil merupakan usaha yang memiliki kekayaan lebh dari $\mathrm{Rp} 50.000 .000$ sampai dengan $\mathrm{Rp}$ 500.000.000 tidak termasuk tanah dan bangunan tempat usaha. Usaha ini juga tercermin dari hasil penjualan tahunan antara Rp 300.000.00 sampai dengan Rp 2.500.000.000. Karakteristik yang melekat pada sebagian besar usaha kecil meliputi 1) masih rendahnya kualitas sumber daya manusia yang dimiliki, 2) rendahnya produktivitas tenaga kerja, 3) rendahnya kualitas barang yang dihasilkan, 4) lemahnya struktur permodalan, 5) rendahnya daya inovasi dan 6) kurangnya akses pemasaran ke pasar potensial. Usaha kecil merupakan kegiatan usaha yang mampu menciptakan lapangan kerja dan memberikan pelayanan ekonomi secara luas keapada masyarakat. Selain itu, usaja kecil merupakan pilar ekonomi nasional yang harus memeroleh kesempatan utama, dukungan, perlindungan dan pengembangan seluas-luasnya sebagai wujud keberpihakan yang tegas kepada kelompok usaha ekonomi rakyat. Keberadaan dan peningkatan jumlah sektor usaha kecil akan memengaruhi permintaan kredit.

Produksi total suatu negara diukur secara nasional dengan Produk Domestik Bruto (PDB), sedangkan untuk daerah disebut PDRB. Cara perhitungan kedua konsep tersebut sama. PDB atau PDRB dapat dihitung atau diukur dengan 3 (tiga) macam pendekatan, yaitu pendekatan produksi, pendekatan pendapatan dan pendekatan pengeluaran. Pendekatan produksi, diartikan sebagai penjumlahan nilai tambah dari setiap barang dan jasa yang dihasilkan oleh suatu negara dalam periode tertentu. Pendekatan pendapatan, adalah pendekatan pendapatan nasional yang menghitung jumlah pendapatan yang diterima oleh pemilik faktor produksi yang digunakan untuk memproduksi barang dan jasa suatu negara dalam satu periode tertentu.
Pendekatan pengeluaran adalah pendekatan yang menghitung pendapatan nasional dari jumlah pengeluaran seluruh pelaku ekonomi, baik di dalam negeri maupun luar negeri selama satu periode tertentu.

PDRB adalah indikator ekonomi makro untuk suatu daerah tertentu. PDRB pada dasarnya merupakan total nilai barang dan jasa akhir yang dihasilkan oleh seluruh unit di suatu region dalam periode tertentu (Produk Domestik Regional Bruto Provinsi Bali, 2020). PDRB juga sering dianggap sebagai ukuran dari kinerja suatu perekonomian. Membaiknya kondisi perekonomian suatu daerah akan meningkatkan pertumbuhan ekonomi serta akan meningkatkan permintaan kredit. Sebaliknya jika dalam kondisi perekonomian yang melemah (resesi) maka permintaan kredit cenderung menurun. Peningkatan PDRB merupakan salah satu indikator kondisi usaha dalam suatu daerah dalam kondisi baik. Kondisi ini membawa dampak posistif bagi para pelaku usaha untuk dapat melakukan ekspansi usaha. Ekspansi usaha tidak akan bisa lepas dari adanya kebutuhan modal. Sumber modal bagi pelaku usaha adalah kredit perbankan.

Bunga bank merupakan balas jasa yang diberikan oleh bank yang berdasarkan prinsip konvensional kepada nasabah yang membeli atau menjual produknya (Suarmanayasa, 2020). Bunga juga dapat diartikan sebagai harga yang harus dibayar kepada nasabah (bunga simpanan) dan harga yang harus dibayar oleh nasabah (bunga kredit). Besar kecilnya suku bunga kredit ditentukan oleh beberapa hal seperti biaya dana, biaya operasi, cadangan risiko kredit macet, laba yang diinginkan bank serta pajak (Kasmir, 2015). (Arianti \& Abdullah, 2021) menyebutkan bahwa permintaan kredit akan dipengaruhi oleh suku bunga kredit. Kenaikan suku bunga kredit akan berdampak pada penurunan jumlah kredit yang diminta sedangkan penurunan suku bunga akan menaikkan jumlah kredit yang diminta. Suku bunga merupakan salah satu pertimbangan bagi pelaku usaha untuk melakukan permohonan kredit. Bila suku bunga kredit tinggi, maka ada kecenderungan pelaku usaha untuk mengurungkan niatnya untuk melakukan permohonan kredit karena beban bunga yang harus dibayar beserta pokok pinjaman akan sangat memberatkan. Sebaliknya, jika suku bunga kredit rendah 
maka permohonan kredit akan dilakukan karena beban bunga dirasa tidak terlalu memberatkan.

Indeks harga konsumen (IHK) menunjukkan perbandingan harga sejumlah baranag dan jasa yang sama pada tahun tertentu terhadap tahun dasar. IHK juga menunjukkan perubahan biaya hidup seseorang atau masyarakat dilihat dari perubahan harga barang dan jasa yang dikonsumsi. Menurut (Muin, 2019), IHK merupakan angka indeks yang menunjukkan tingkat harga barang dan jasa yang harus dibeli konsumen dalam satu periode tertentu. IHK dapat dapat digunakan untuk mengetahui tingkat inflasi. Peningkatan angka IHK mengindikasikan peningkatan harga. (Amelia, 2019) menyatakan bahwa inflasi yang mencerminkan kenaikan hargaharga relatif barang dan jasa di masa datang akan menyebabkan peningkatan terhadap jumlah kredit yang diminta. Hal ini akan memaksa para pelaku usaha untu memeroleh tambahan dana dari pihak perbankan untuk memastikan keberlangsungan usahanya. Dapat dikatakan bahwa peningkatan IHK secara tidak langsung akan memaksa para pelaku usaha untuk mencari tambahan dana melalui kredit.

Penelitian ini bertujuan untuk menganalisis pengaruh jumlah usaha kecil, PDRB, suku bunga kredit dan indeks harga konsumen baik secara simultan maupun parsial terhadap jumlah kredit modal kerja untuk usaha kecil di Bali. Diharapkan penelitian ini berkontribusi baik secara praktis maupun secara akademik. Secara akademik, semoga hasil penelitian ini dapat menambah dan memperkaya khasanah ilmu pengetahuan. Secara praktis, semoga hasil ini dapat dijadikan acuan atau bahan pertimbangan bagi pelaku usaha atau pihak perbankan dalam membuat keputusan kredit.

\section{METODE}

Lokasi penelitian adalah di Provinsi Bali. Ruang lingkup penelitian terbatas pada pengaruh variabel jumlah usaha kecil, PDRB, suku bunga kredit modal kerja, dan indeks harga konsumen terhadap jumlah kredit modal kerja untuk usaha kecil. Data yang digunakan adalah data kuantitatif berupa data jumlah usaha kecil, PDRB, suku bunga, dan indeks harga konsumen. Data yang digunakan memiliki rentang waktu 8 tahun dan berbentuk data triwulanan. Jenis data berupa data sekunder yang bersumber dari Badan Pusat Statistik, Otoritas Jasa Keuangan dan Bappeda Provinsi Bali.

Variabel-variabel dalam penelitian ini dibedakan menjadi dua kelompok yaitu, 1) variabel terikat (dependent variable) yang terdiri atas variabel jumlah kredit modal kerja; 2) variabel bebas (indefendent variable) yang terdiri atas variabel jumlah usaha kecil, PDRB, Suku bunga kredit modal kerja dan indeks harga konsumen. Adapun definisi operasional dari masing-masing variabel adalah sebagai berikut : 1 . Jumlah kredit modal kerja adalah jumlah kredit yang diberikan bank-bank umum di Bali untuk keperluan modal kerja yang disalurkan khusus untuk usaha kecil, 2. Jumlah usaha kecil adalah jumlah usaha yang berpenghasilan tahunan lebih dari 300 juta sampai dengan paling banyak 2,5 milyar rupiah yang berlokasi di Provinsi Bali, 3) PDRB adalah total nilai barang dan jasa akhir yang dihasilkan oleh sektor-sektor di Provinsi Bali, 4) Suku bunga kredit adalah suku bunga khusus bagi kredit untuk keperluan modal kerja, dan 5) indeks harga konsumen adalah rasio yang menunjukkan perbandingan harga sejumlah barang dan jasa yang sama pada tahun tertentu terhadap tahun dasar. Data yang diperlukan dikumpulkan dengan menggunakan metode dokumentasi. Teknik analisis data yang digunakan yaitu analisis regresi linier berganda model double log. Analisis dibantu dengan program SPSS Versi 22.0 For Windows.

\section{HASIL DAN PEMBAHASAN}

Penelitian ini menggunakan model regresi linear berganda model double log. Analisis ini bertujuan untuk mendapatkan hasil taksiran regresi yang terbaik yaitu model yang memiliki nilai koefisien determinasi yang tertinggi dan tidak mengandung unsur pelanggaran asumsi klasik (uji normalitas, multikoliniearitas, heteroskedastisitas dan autokorelasi). 
Tabel 1. Hasil Penaksiran Regresi dengan Model Double Log

\begin{tabular}{lccrc}
\hline Variabel Bebas & $\begin{array}{c}\text { Koefisien } \\
\text { Regresi }\end{array}$ & $\begin{array}{c}\text { Standar } \\
\text { Error }\end{array}$ & t- hitung & Sig \\
\hline LnJumlah Usaha Kecil $\left(\mathrm{X}_{1}\right)$ & 0,051371 & 0,254710 & 0,201684 & 0,8417 \\
LnPDRB $\left(\mathrm{X}_{2}\right)$ & 0,351416 & 0,101966 & 3,446390 & 0,0019 \\
LnSuku Bunga $\left(\mathrm{X}_{3}\right)$ & $-0,657662$ & 0,056621 & $-11,61509$ & 0,0000 \\
LnIndeks harga konsumen $\left(\mathrm{X}_{4}\right)$ & 0,312415 & 0,145344 & 2,149481 & 0,0407 \\
Konstanta & 8,360171 & & & \\
R Square $\left(\mathrm{R}^{2}\right)$ & 0,991942 & & \\
F-hitung & 830,8838 & & \\
Sig & 0,000 & & & \\
\hline
\end{tabular}

Sumber: Data diolah

Berdasarkan rangkuman hasil analisis data yang terdapat pada Tabel 1 maka dapat diperoleh persamaan regresi sebagai berikut :

$$
\begin{aligned}
\operatorname{Ln} \hat{Y}= & 8,36+\operatorname{Ln} 0,0,05 X_{1}+\operatorname{Ln} 0,35 X_{2} \\
& -\operatorname{Ln} 0,66 X_{3}+\operatorname{Ln} 0,31 X_{4}
\end{aligned}
$$

Berdasarkan Tabel 1 dapat dijelaskan bahwa secara simultan variabel jumlah usaha kecil, PDRB, suku bunga kredit modal kerja dan indeks harga konsumen berpengaruh signifikan terhadap jumlah kredit modal kerja untuk usaha kecil. Hal ini ditunjukkan dengan nilai signfikansinya yang lebih kecil dari 0,05. Secara parsial, jumlah usaha kecil tidak berpengaruh terhadap jumlah kredit modal kerja untuk usaha kecil, ini dibuktikan dengan nilai signifikansinya yang lebih besar dari 0,05. Variabel PDRB dan indeks harga konsumen secara parsial berpengaruh positif dan signifikan terhadap jumlah kredit modal kerja untuk usaha kecil dengan nilai signifikansi lebih kecil dari 0,05. Variabel suku bunga kredit berpengaruh negatif dan signifikan terhadap jumlah kredit modal kerja untuk usaha kecil dengan nilai signifikasi lebih kecil dari 0,05. Nilai koefisien determinasi sebesar 0,992 memiliki arti bahwa 99,2 persen variasi (naik turunnya) jumlah kredit modal kerja untuk usaha kecil pada bank umum di Bali dapat dijelaskan oleh variasi (naik turunnya) jumlah usaha kecil, PDRB, suku bunga, dan indeks harga konsumen. Sisanya sebesar 0,8 persen dipengaruhi oleh variabel lain yang tidak dimasukkan dalam model.

Hasil penelitian menemukan bahwa jumlah usaha kecil tidak berpengaruh terhadap jumlah kredit modal kerja untuk usaha kecil di Bali. Temuan ini memberi makna bahwa tidak adanya jaminan jika jumlah usaha kecil banyak menjadikan jumlah kredit yang disalurkan untuk usaha kecil juga banyak, begitu pula sebaliknya. Adanya peralihan skala usaha bisa menjadi penyebab kondisi ini. Misalkan, bila tenaga kerja suatu usaha bertambah maka skala usaha akan bertambah dan cenderung menjadi usaha berskala besar.

Bila jumlah tenaga kerja berkurang maka skala usaha cenderung berkurang dan menjadi usaha berskala mikro. Temuan ini berbeda dengan hasil penelitian (Aristanto, 2019) yang menemukan bahwa salah satu penyebab fluktuasi permintaan kredit disebabkan oleh adanya fluktuasi jumlah usaha. Artnya, jumlah sektor usaha akan sangat menentukan jumlah permintaan kredit untuk modal kerja. Umumnya, para pelaku usaha yang ingin membangun atau mengembangkan usahanya akan membutuhkan banyak dana. Salah satu sumber dana yang selalu menjadi pilihan pelaku usaha adalah kredit perbankan. Jadi, seiring dengan adanya peningkatan jumlah usaha tentunya akan memengaruhi peningkatan permintaan kredit.

Nilai koefisien PDRB sebesar 0,35 memiliki arti bahwa jika PDRB meningkat satu persen maka jumlah kredit modal kerja untuk usaha kecil di Bali meningkat sebesar 0,35 persen dengan asumsi jumlah usaha kecil, suku bunga dan indeks harag konsumen tetap, begitu pula sebaliknya. Hasil ini sejalan dengan penelitian (Ramandhana et al., 2018) yang menemukan bahwa meningkatnya pertumbuhan ekonomi 
akan meningkatkan permintaan kredit dan sebaliknya dalam kondisi perekonomian yang melemah (resesi) maka permintaan kredit cenderung menurun. (Naibaho \& Rahayu, 2018) menegaskan bahwa kondisi perekonomian yang baik akan menaikkan permintaan kredit.

Peningkatan PDRB sebagai indikasi membaiknya kondisi perekonomian suatu daerah. (Awandari \& Indrajaya, 2016), menegaskan bahwa pertumbuhan ekonomi mendorong terjadinya peningkatan kemakmuran masyarakat. Kemakmuran akan ditandai dengan adanya peningkatan pendapatan masyarakat. Bila pendapatan masyarakat meningkat maka permintaan akan barang dan jasa juga akan meningkat. $\mathrm{Hal}$ ini akan berdampak pada keuntungan para pelaku usaha. Sebagai homo economicus yang cenderung profit oriented maka pelaku usaha akan mengejar keuntungan sebanyak-banykanya dengan cara meningkatkan produksinya. Agar mampu menambah jumlah produksi maka kredit perbankan adalah salah satu solusi untuk membantu pelaku usaha dalam hal permodalan.

Pertumbuhan ekonomi yang baik akan memengaruhi perkembangan dunia usaha. Semakin tinggi pertumbuhan ekonomi maka akan ada kecenderungan peningkatan daya beli masyarakat yang berimbas pada peningkatan volume penjualan bagi pelaku usaha.hal ini akan menuntut pelaku usaha untuk meningkatkan produksi seiring dengan peningkatan permintaan masyarakat. Peningkatan produksi memebutuhkan tambahan dana yang dapat diperoleh dari pihak perbankan berupa kredit modal kerja. (Suarmanayasa, 2020) menegaskan bahwa tinggi rendahnya permintaan kredit dipengaruhi oleh kondisi ekonomi. Kondisi ekonomi yang baik akan menciptakan lingkungan sektor riil yang kondusif. Hal ini akan menjadi kabar gembira bagi perkembangandunia usaha untuk melakukan ekspansi usaha.

Jadi dapat dikatakan bahwa peningkatan PDRB akan berimbas pada peningkatan pendapatan masyarakat yang nantinya akan memengaruhi daya beli masyarakat. Seiring dengan meningkatnya daya beli masyarakat maka akan berpengaruh terhadap volume penjualan produk usaha. Hal ini menuntut pelaku usaha untuk meningkatkan produksinya. Untuk mampu menambah jumlah produksi diperlukan tambahan dana. Tambahan dana dapat diperoleh dari perbankan berupa kredit modal kerja.

Nilai koefisien suku bunga kredit sebesar -0,66 memiliki arti bahwa jika suku bunga kredit meningkat sebesar satu persen maka jumlah kredit modal kerja untuk usaha kecil mengalami penurunan sebesar 0,66 persen dengan asumsi jumlah usaha, PDRB, dan indeks harga konsumen tetap, begitu pula sebaliknya. Hasil ini sejalan dengan temuan (Soeharjoto, 2019) yang menemukan bahwa bila tingkat suku bunga meningkat akan menurunkan jumlah kredit UMKM di Provinsi Kalimantan Timur, dan sebaiknya bila tingkat suku bunga turun akan menaikkan jumlah kredit UMKM di Provinsi Kalimantan Timur. Hasil ini juga sejalan dengan penelitian (Suarmanayasa, 2020) yang menemukan bahwa ketika suku bunga turun maka porsi kredit untuk usaha kecil meningkat.

(Riyadi, 2020) menegaskan bahwa dari tiga variabel yang memengaruhi permintaan kredit umkm di provinsi aceh, suku bunga perbankan adalah variabel yang paling berpengaruh dan signifikan terhadap penyaluran kredit umkm. Ini memiliki arti bahwa semakin tinggi bank mengenakan suku bunga kredit, minat masyarakat untuk meminjam kredit semakin berkurang, sebab mereka dihadapkan dengan jumlah pembayaran kredit ditambah bunga yang tinggi. Kondisi ini memberatkan masyarakat dalam meminjam kredit dan melunasi kreditnya di masa akan datang. Namun sebaliknya, apabila bank mengenakan suku bunga kredit yang rendah maka minat masyarakat dalam meminjam kredit bertambah besar, khususnya kredit untuk usaha kecil. Masyarakat akan memmiliki keyakinan bahwa mereka akan mampu melunasi pinjamanya di masa yang akan datang. (Pratiwi \& Adriati, 2020) menambhakan bahwa suku bunga kredit dan jumlah kredit yang disalurkan merupakan dua hal yang saling berhubungan. Suku bunga kredit merupakan sumber utama keuntungan dari pihak perbankan (Spread based). Tetapi terkadang, suku bunga kredit dapat berdampak pada penyaluran kredit itu sendiri. Semakin tinggi suku bunga kredit maka penyaluran kredit perbankan akan turun karena mahalnya biaya dan sebaliknya jika suku bunga kredit turun maka permintaan 
kredit perbankan dari masyarakat akan meningkat karena semakin rendahnya biaya. Nilai koefisien indeks harga konsumen sebesar 0,31 memiliki arti bahwa jika indeks harga konsumen meningkat sebesar satu persen maka jumlah kredit modal kerja untuk usaha kecil mengalami peningkatan sebesar 0,31 persen dengan asumsi jumlah usaha, PDRB dan suku bunga kredit tetap, begitu pula sebaliknya. Hasil penelitian ini mendukung penelitian (Hendiani, 2017) yang menemukan bahwa inflasi yang mencerminkan ekspektasi terhadap kenaikan harga-harga relatif barang dan jasa di masa datang akan menyebabkan kenaikan jumlah kredit yang diminta. Adanya peningkatan harga menyebabkan pelaku usaha mencari tambahan dana untuk meningkatkan jumlah produksi. Hal yang sama ditegaskan oleh (Amelia, 2019) yang menyatakan bahwa inflasi dapat meningkatkan produksi dengan asumsi produksi mengalami kenaikan mendahului kenaikan upah dan gaji pekerja. Kenaikan harga menciptakan keuntungan (laba) bagi pelaku usaha. Keuntungan yang telah dinikmati oleh pelaku usaha akan mendorong pelaku usaha untuk terus meningkatkan produksinya. (Arianti \& Abdullah, 2021) menambahkan bahwa kenaikan harga akan mendorong konsumsi lebih awal sebelum harga naik dan kredit merupakan salah satu sumber dana bagi pelaku usaha.

\section{SIMPULAN DAN SARAN}

Berdasarkan hasil pembahasan yang telah dipaparkan sebelumnya maka dapat dibuat simpulan sebagai berikut: 1) jumlah usaha kecil, PDRB, suku bunga kredit dan indeks harga konsumen secara simultan berpengaruh signifikan terhadap jumlah kredit modal kerja pada usaha kecil di Bali, 2) Jumlah usaha kecil tidak berpengaruh terhadap jumlah kredit modal kerja, 3) Suku bunga kredit berpengaruh negatif dan signifikan terhdap jumlah kredit modal kerja, 4) PDRB berpengaruh positif dan signifikan terhadap jumlah kredit modal kerja, dan 5) Indeks harga konsumen berpengaruh positif dan signifikan terhadap jumlah kredit modal kerja untuk usaha kecil di Bali. Berkaitan dengan hal tersebut maka adapun saran yang bisa diberikan kepada pihak perbankan adalah diharapkan bank-bank umum memberikan kemudahan bagi pelaku usaha kecil dalam proses perolehan kredit modal kerja untuk membantu keberlanjutan usaha kecil. Kontribusi akademik yang dapat disampaikan adalah bahwa penyaluran kredit untuk usaha kecil memiliki kekhasan khusus. Terbukti hasil penelitian menemukan bahwa jumlah usaha kecil tidak berpengaruh terhadap jumlah kredit modal kerja. Hal ini menegaskan bahwa karakteristik dan tantangan yang dihadapi usaha kecil berbeda dengan jenis usaha lainnya. Dalam penelitian ini terdapat keterbatasan yang dapat dijadikan bahan pertimbangan bagi peneliti selanjutnya. Keterbatasan yang dimaksud adalah penggunaan 4 variabel independen, padahal masih banyak variabel lain yang dapat memengaruhi penyaluran kredit.

\section{REFERENSI}

Amelia, E. A. (2019). Pengaruh Capital Adequacy Ratio ( CAR ), Inflasi dan Financing to Deposit Ratio ( FDR ) terhadap non Performing Financing ( NPF ) pada Bank Umum Syariah Periode 2015-2017 Pendahuluan Perekonomian di suatu negara tidak lepas dari dunia keuangan dan perbank. Jurnal Intelektualita: Keislaman, Sosial Dan Sains, 8(1), 11-18.

Arianti, R. N., \& Abdullah, F. (2021). Analisis Pengaruh Suku Bunga, Inflasi dan Pdb Terhadap Jumlah Permintaan Kredit Perbankan di Indonesia Tahun 20092019. Jurnal IImu Ekonomi (JIE), 5(1), 103-117.

Aristanto, E. (2019). Kredit Usaha Rakyat (KUR): Pilihan Kebijakan Afirmatif Mendorong Pengembangan Usaha Mikro, Kecil, dan Menengah di Indonesia. Journal of Banking and Finance, 1(1), 10-23.

Awandari, L. P. P., \& Indrajaya, I. G. B. (2016). Pengaruh Infrastruktur, Investasi, dan Pertumbuhan Ekonomi terhadap Kesejahteraan Masyarakat melalui Kesempatan Kerja. E-Jurnal Ekonomi Pembangunan Universitas Udayana, 5(16), 1435-1462.

Produk Domestik Regional Bruto Provinsi Bali, (2020). www.bps.go.id

Hendiani, R. (2017). Analisis pengaruh tingkat suku bunga, pdb perkapita dan indeks harga konsumen terhadap jumlah uang beredar indonesia periode 2001-2015. Universitas Jenderal Soedirman.

Indriani, M. (2016). Peran Tenaga Kerja 
Indonesia dalam Pembangunan

Ekonomi Gema Keadilan Edisi Jurnal. Gema Keadilan, 1(1), 67-77.

Kasmir. (2015). Manajemen Perbankan Edisi Revisi. PT Raja Grafindo Persada.

Muin, M. (2019). Analisis Indeks Harga Konsumen di Indonesia Melalui Pendekatan Kointegrasi. Jurnal REP (Riset Ekonomi Pembangunan), 4(2), 110-118.

https://doi.org/10.31002/rep.v4i2.1753

Naibaho, K., \& Rahayu, S. M. (2018). Pengaruh gdp, inflasi, bi rate, nilai tukar terhadap non performing loan pada bank umum konvensional di indonesia. Jurnal Administrasi Bisnis (JAB), 62(2), 87-96.

Pratiwi, N. M. D., \& Adriati, I. G. A. W. (2020). Dampak Penurunan Suku Bunga Kredit terhadap Penyaluran Kredit di LPD Kuta Saat Pandemi Covid-19. WIDYA MANAJEMEN, 2(2), 81-87. https://doi.org/2020

Undang-Undang tentang Usaha Mikro, Kecil dan Menengah, (2008).

Putra, I. G. O. P., \& Rustariyuni, S. D. (2014). Penyaluran Kredit Modal Kerja Pada Bpr Di Provinsi Bali Tahun 2009-2014. E-Jurnal EP UNUD, 4(5), 451-464.

Ramandhana, D. Y., Jayawarsa, A. A. K., \& Aziz, S. A. (2018). Pengaruh Inflasi, Suku Bunga BI Rate, Pertumbuhan Ekonomi, Non Performing Loan (NPL) dan Capital Adequa- cy Ratio (CAR) terhadap Penyaluran Kredit Usaha Rakyat (KUR) pada Bank Umum di Indonesia Periode 2013-2017. Warmeda Economic Development Journal, 1(1), 30-40.

Risal, T. (2019). Peningkatan peran perbankan syariah dengan menggerakkan sektor riil dalam pembangunan. Accumulated, 1(1), 36$47 . \quad$ http://e-journal.potensiutama.ac.id/ojs/index.php/Accumulated/ article/view/581/794

Riyadi, R. (2020). Faktor-Faktor yang Mempengaruhi Permintaan Kredit Umkm Di Provinsi Aceh. Universitas Syiah Kuala.

Soeharjoto. (2019). Determinasi Penyaluran Kredit UMKM di provinsi Kalimantan Timur. Forum Ekonomi, 21(2), 226-234.

Suarmanayasa, I. N. (2020). Pengaruh Dana Pihak Ketiga, Modal Bank, Bunga Kredit, Bunga Sbi Dan Kredit Periode
Sebelumnya Terhadap Kredit Yang Diberikan Bank Umum. Bisma: Jurnal Manajemen, $6(1)$ 8. https://doi.org/10.23887/bjm.v6i1.24388 